\title{
Hagiografía y censura en el teatro clásico
}

\author{
Hagiography and Censorship in Theater \\ of the Golden Age
}

\author{
Héctor Urzáiz Tortajada \\ Universidad de Valladolid
}

\section{RESUMEN}

Se estudia la censura de 24 comedias manuscritas de temática religiosa, sobre todo hagiográfica, fechadas entre 1600-1745; la mayoría son obras o autores poco conocidos: La loca del cielo, El hijo del Serafín, La aurora del sol divino, El negro del Serafín, Lo que toca al valor, El príncipe perseguido, Cegar para ver mejor, San Cayetano, San Blas, El pleito del Demonio con la Virgen, El bruto de Babilonia, La adúltera penitente, Será lo que Dios quisiere, La hija del Serafín, El José de las mujeres, Santa Catalina, El más divino remedio, El iris de las tormentas, Santa Táez, El sol de Occidente, Ángel, milagro y mujer, La conversión de la Magdalena, La gran Rosa de Viterbo y El bello iris setabitano. Casi toda la abundante información que se proporciona es inédita o complementa otras informaciones anteriores parciales o erróneas. Se aportan también numerosos ejemplos desconocidos de intervención de la Inquisición en la censura previa y de otros aspectos de la actividad de los censores: las relaciones entre ellos, los plazos y procedimientos de su trabajo, su preocupación por asuntos literarios, histórico-geográficos, teatrales, etc.

Palabras Clave: teatro clásico; siglos XVII y XVIII; censura; hagiografía; Inquisición.

\begin{abstract}
The purpose of this paper is to study from the point of view of the teatrical censorship 24 religious and hagiographic comedies, dated from 1600 to 1745. Most of these plays are almost unknown: La loca del cielo, El hijo del Serafín, La aurora del sol divino, El negro del Serafín, Lo que toca al valor, El príncipe perseguido, Cegar para ver mejor, San Cayetano, San Blas, El pleito del Demonio con la Virgen, El bruto de Babilonia, La adúltera penitente, Será lo que Dios quisiere, La hija del Serafín, El José de las mujeres, Santa Catalina, El más divino remedio, El iris de las tormentas, Santa Táez, El sol de Occidente, Ángel, milagro y mujer, La conversión de la Magdalena, La gran Rosa de Viterbo y El bello iris setabitano. The information provided (concerning the intervention of the Inquisition, the relationships between the censors, the terms and procedures of their work) is also new and unknown.
\end{abstract}

Key words: Spanish theater of the Golden Age; Censorship; Hagiography; Inquisition. 
Pretendemos en las próximas páginas analizar un corpus de veinticuatro obras teatrales de los siglos XVI al XVIII desde el punto de vista de la censura. El corpus seleccionado para el análisis se ha acotado en función de su soporte material (manuscritos), su contenido temático (comedias religiosas, sobre todo de tipo hagiográfico) y su cronología (fijando el límite temporal a mediados del XVIII para abarcar tanto el teatro barroco como el tardobarroco y la transición al neoclásico $\left.{ }^{1}\right)$.

La mayor parte de los códices analizados son manuscritos de representación que aportan una serie de interesantes informaciones tanto para la historia de la censura, puesto que contienen licencias de representación y diversas intervenciones de los examinadores, como para la historia de la puesta en escena, dado que suelen presentar gran profusión didascálica (en las versiones impresas las acotaciones escénicas solían desestimarse ${ }^{2}$ ). Este último aspecto es particularmente apreciable en el caso de las comedias religiosas y hagiográficas que nos van a ocupar, puesto que la espectacularidad escénica y las grandes tramoyas eran características de este subgénero dramático, cuya popularidad fue en aumento a lo largo de los siglos XVII y XVIII. María José del Río Barredo ya señaló hace años el vínculo entre esta peculiaridad formal y el gusto popular por las comedias religiosas:

Las comedias de tema sagrado tenían como primer objetivo excitar la piedad de los fieles exponiendo, de modo fácil y agradable, algunos aspectos de la doctrina cristiana, relatos de la historia sagrada y de las vidas de santos [...] El significado de estas nociones se transmitía, además y sobre todo, mediante símbolos escenográficos; precisamente era la abundante utilización de decorados y maquinaria en la puesta en escena lo que había hecho de estas representaciones las predilectas de un público cortesano en el siglo XVII y de la audiencia popular en el XVIII (Río Barredo, 1986: 285).

Dado que estas comedias de santos o de temática sagrada, por su propia naturaleza, obviamente «debían conformar con un cierto canon de decencia» (Ruano de la Haza, 1989: 225), y que ya desde antiguo las autoridades eclesiásticas habían perseguido la mezcla de lo cómico y lo sagrado en el teatro, así como los excesos que el propio culto popular a los santos podía generar, la censura las vigilaba con celo extremo; como ha señalado Jesús Menéndez, las constituciones sinodales posteriores al Concilio de Trento (como las de Toledo, 1583) reflejarán el rigorismo contrarreformista del «nuevo espíritu tridentino»:

\footnotetext{
${ }^{1}$ Este artículo, de hecho, es fruto de las investigaciones del grupo CLEMIT (Censuras y licencias en manuscritos e impresos teatrales), desarrolladas en los últimos años desde la Universidad de Valladolid gracias a dos proyectos I+D del Plan Nacional que abarcaron respectivamente el siglo XVII y la primera mitad del XVIII (HUM2006-06590/FILO y FFI2009-09076). Remitimos a la página clemit.es y su base de datos (buscador.clemit.es) para la ampliación de los detalles textuales que aquí no tienen cabida.

2 «Los impresores acostumbran a hacer mangas y capirotes con estos elementos, cuya literalidad nunca consideraron digna de ser conservada» (Rodríguez Cáceres, 2011: 1278).
} 
[El Concilio de Trento] dejó patente el mimo con que se había de celebrar la misa (sesión 22) y el culto a los santos (sesión 25), dos aspectos del culto litúrgico que tendrán una repercusión directa en nuestro teatro religioso a través del auto religioso y de la comedia hagiográfica. En el Concilio de Trento hubo conciencia de las aberraciones a que daban lugar determinados ritos litúrgicos, como [...] el culto a los santos [...] El Concilio de Trento marcará, pues, un hito en el control de las representaciones (Menéndez Peláez, 2005: 56-58).

Teniendo en cuenta, además, que las comedias religiosas y hagiográficas se apoyaban en gran medida en la espectacularidad de su puesta en escena (milagros, apariciones, torturas, vuelos angélicos o demoniacos) y que, pese a lo delicado de la temática, no renunciaban tampoco al humor para ganarse al público, los excesos en uno y otro terreno podían propiciar fácilmente un morbo y una hilaridad que eran poco del gusto de los guardianes de la fe y las buenas costumbres ${ }^{3}$. Incluso si nos trasladamos a otros ámbitos donde se han estudiado los documentos de la censura teatral se constata este énfasis en el control de las comedias hagiográficas; valga como ejemplo el caso de la Nueva España:

En nuestros documentos predomina la censura inquisitorial a las comedias de santos [en el siglo XVII], mismas que, pese a no ser todavía abiertamente perseguidas, sí eran severamente vigiladas y, por ende, analizadas, evaluadas y juzgadas. Y dependiendo de cuán nocivas o peligrosas se llegaran a considerar (Ramos Smith, 1998: 186-187).

De hecho, las comedias de santos llegarían a ser prohibidas en España en 1748 (de 1744 es la última censura que vamos a analizar aquí), aunque la correspondiente cédula de prohibición «no ha aparecido», como señala Antonio Roldán, motivo por el cual siempre se da 1765 como fecha de la prohibición:

Sobre el papel fueron prohibidas las Comedias de Santos por Real Cédula de 9 de junio de 1765; pero surgen varias preguntas, como por ejemplo: ¿Qué valor tuvo, en la práctica, la prohibición de las comedias de santos de 1748, cuyo texto todavía hoy no se ha encontrado? (Roldán Pérez, 1998: 128).

Precisamente es en este caso de las comedias hagiográficas el único en el que el citado investigador, especialista en censura inquisitorial (sobre cuyas tesis al respecto del teatro, sin embargo, discrepo: Urzáiz, 2012a), reconoce que están documentadas intervenciones del Santo Oficio previas a su representación incluso en el siglo XVII:

[Los tres portentos de Dios, de Vélez de Guevara, y Las misas de San Vicente Ferrer, de Enríquez Gómez] son casos clarísimos de censura inquisitorial previa

\footnotetext{
${ }^{3}$ Algunos casos interesantísimos, y muy bien estudiados por otros investigadores, son La Santa Juana, de Tirso de Molina (Florit, 2005), y El purgatorio de San Patricio, de Calderón (1988).
} 
a la representación para los que no encuentro explicación aceptable. ¿Por ser Comedias de Santo? (Roldán Pérez, 1998: 127)4

Veamos, pues, otra serie de manuscritos de representación de comedias religiosas de los siglos XVII y XVIII (la mayoría de ellas muy poco conocidas o de autores escasamente frecuentados), para intentar refrendar esa hipótesis y aportar detalles concretos de su reflejo en los testimonios conservados. En la Biblioteca Histórica de Madrid se conservan los manuscritos de dos comedias hagiográficas de título similar: El hijo del Serafín, San Pedro de Alcántara, de Juan Pérez de Montalbán (dramaturgo en vías de recuperación gracias a un reciente proyecto editorial ${ }^{5}$ ) y La hija del Serafín, y tercera de Toledo, de Tomás Manuel de Paz (autor prácticamente desconocido). La comedia de Montalbán sobre el fraile franciscano San Pedro de Alcántara (14991562), escrita en 1634, se conserva en un manuscrito fechado en 1666 (Tea1-66-13) cuyas censuras se han perdido, aunque su descripción catalográfica en red todavía hoy señala que contiene «diligencias administrativas para la representación»; en realidad, y por desgracia, los únicos paratextos que conserva (que no dejan de ser interesantes, como tantas otras notas domésticas, chascarrillos y pequeñas historias cotidianas plasmadas en estos códices teatrales) son los que dan cuenta de que «los señores Justicia y Regimiento [de Valladolid] han hecho postura en la cebada a diecisiete cuartos el celemín de lo que se vende sin paja en los cajones y a diecinueve con ella en los mesones, y a este precio se ha de vender sin exceder, pena de incurrir de las ordenanzas»... Pero los atajos textuales marcados sobre el manuscrito de El hijo del Serafín permiten admitir como hipótesis esas intervenciones de la censura, sobre todo en escenas tan características de las comedias hagiográficas como las descritas por acotaciones como éstas (donde se introduce al Demonio, un personaje que va a concurrir con asiduidad en las próximas páginas ${ }^{6}$ ): «Tocan cajas y descúbrese el rey de rodillas lleno de sangre; y algunos con él, heridos»; «Salen el Demonio y el santo, ya con barba entrecana, luchando los dos» (ff. 29r-30v).

\footnotetext{
${ }^{4}$ Creo haber demostrado, a través de otros muchos ejemplos (y no solo de obras de temática religiosa), la existencia de una censura inquisitorial previa para el teatro, aunque fuera eventual y oficiosa, ya en el siglo XVII. También he publicado los expedientes inquisitoriales completos de esas dos comedias citadas por Roldán como supuestos «casos únicos» (Urzáiz, 2012a y 2012c).

${ }^{5}$ Encabeza Claudia Demattè la Biblioteca de Autor de Montalbán en el portal de la Biblioteca Virtual Miguel de Cervantes «Teatro Clásico Español», dirigido por Germán Vega García-Luengos.

${ }^{6}$ Como dice Javier Rubiera en su estudio sobre la comedia hagiográfica El José de las mujeres, de Calderón de la Barca, «la introducción del personaje del demonio en una obra teatral lleva siempre consigo una fuerte carga de espectacularidad en consonancia con los extraordinarios poderes físicos de la figura diabólica... [El Demonio] se convierte en un improvisado, pero auténtico, director de escena que mueve los hilos de la representación» (Rubiera, 2006: 545).
} 
Sí nos han quedado, en cambio, las licencias de representación de La hija del Serafín, y tercera de Toledo, de Manuel de Paz, dedicada a Santa Mariana de Jesús (Quito, Ecuador, 1618-1645). El manuscrito que la contiene está fechado en 1678 y en su portada se reseña la aprobación inquisitorial que recibió: «Comedia nueva La hija del Serafín, y tercera de Toledo, por Tomás Manuel de Paz. Aprobada por la Suprema Inquisición. Año 1678». Este manuscrito contiene la correspondiente nota de la censura, extendida «de orden del señor Inquisidor General y demás señores de la Suprema Inquisición de España» por «el maestro don Juan de Rueda y Cuevas», del que volveremos a hablar más adelante. En esta ocasión, el censor no sólo no encontró en esta comedia sobre la Azucena de Quito «cosa contra nuestra santa fe y buenas costumbres», sino «antes, grande ejemplar de la providencia de Dios y desengaño del mundo». Como prueba de ello, en el desenlace de La hija del Serafín asistimos al fracaso del Demonio, que también es protagonista aquí: «DEMONIO.- ¡Sepúltenme los abismos, / pues no he logrado mi intento! (Húndese.)».

También en la Biblioteca Histórica de Madrid se conserva la copia de representación de Ángel, milagro y mujer, comedia hagiográfica de Nicolás de Villarroel (BHM, Tea-1-83-4). El manuscrito está fechado en 1698, lleva el segundo título (tachado, por cierto) de Sor Martina de los Ángeles y varias licencias de representación en las que los censores (Agustín Gallo, Pedro Lanini y Francisco Bueno) no reseñaron ninguna objeción. Es una obra donde cobran también gran presencia los bandoleros y el Demonio, personajes característicos de estas comedias hagiográficas con profusión de tramoyas y efectos espectaculares: «Estarán los dos [Golondro y el Demonio] asidos de la cadena, y el Demonio se la quita, echándola en un escotillón por donde subirá una llamarada» (f. 17v); «Va a darla con la daga y baja Sor Martina vestida de monja dominica en un pescante, de suerte que le detenga el brazo» (2a jornada, f. $3 \mathrm{r})$.

Una de esas notas cotidianas a las que nos referíamos antes nos permitirá enlazar este breve comentario sobre Ángel, milagro y mujer, de Villarroel, con otro sobre una interesante comedia religiosa (de un autor cuya sola mención ya nos pone sobre aviso de problemas con la censura y la Inquisición). Aunque se trate de cuestiones laterales, estos pequeños detalles ofrecen a veces sugerentes puntos de conexión con el problema de fondo que estamos abordando, la censura teatral: los comediantes que representaron Ángel, milagro y mujer escribieron sobre su manuscrito una curiosa nota acerca de los procedimientos seguidos para los traslados de las obras teatrales; es decir, las copias utilizadas para la intendencia de los ensayos y en el trabajo de los apuntadores: «Alfonso mío, hazme gusto de sacar esta noche un cuadernillo [de] esta comedia para mañana ensayarla en la casa por tramoyas, y te aviso has de apuntarla en la casa todos los días que se hiciere» (f. 2r).

Pues bien, a propósito de estos traslados pero volviendo a la cuestión que nos ocupa, veamos la curiosa observación que hizo uno de los censores de esa 
otra comedia religiosa a la que nos referíamos, La conversión de la Magdalena, del judío Enríquez Gómez (quien sufrió persecución inquisitorial y a la vuelta de su destierro en 1649 hubo de ocultarse tras el pseudónimo Fernando de Zárate). En una copia de representación fechada en 1699, custodiada en este caso por la Biblioteca Nacional de España (Ms. 16.955), uno de los censores (de nuevo Lanini) ponía algunas pegas y ordenaba que no se dijera «lo que va atajado, por ser escandaloso y contra los preceptos de la ley cristiana», mientras que el otro, Francisco Bueno, menos permisivo, abundaba en que no se podía representar sin suprimir una escena onírica, «una herejía formal» y otros «muchos absurdos malsonantes», y pedía que se mandara a la Inquisición: «Pase por el censor del Santo Tribunal, por que lo diga quien lo debe decir» (f. 1r).

Dicho censor inquisitorial, el también mencionado doctor Agustín Gallo Guerrero (repárese en que son los tres mismos examinadores que habían visto el año anterior Ángel, milagro y mujer), no encontró nada punible tras mirarla «atentamente». Pero lo más llamativo, en relación con lo comentado sobre las copias de actor, es que el censor Francisco Bueno sugería que los despropósitos por él enumerados eran «quizá por culpa de los traslados», concediendo la posibilidad de que algún desliz doctrinal no fuera sino un lapsus calami, aspecto que no siempre se tiene en cuenta ${ }^{7}$.

Los censores entraban a veces en apreciaciones muy particulares cuando caía en sus manos una obra teatral. Veamos, por ejemplo, el caso de El negro del Serafín, de Vélez de Guevara, que se ha conservado en un manuscrito con interesantes censuras de Juan Navarro de Espinosa (BNE, Ms. 17.317) y que se ha identificado con El negro del mejor amo, San Benito de Palermo, comedia de Mira de Amescua denunciada a la Inquisición en 1722 (con un curioso resultado, pues finalmente fue el delator quien sufrió la censura del Santo Tribunal por hacer «gastar el tiempo inútilmente a los inquisidores», Granja, 2006: 438-439).

A Navarro de Espinosa (y a otro examinador del que hablaremos después) le dedicó Ruano de la Haza, hace ya algunos años, el interesante artículo «Dos censores de comedias de mediados del siglo XVII», pero su actividad en la intrahistoria del teatro áureo no deja de ofrecer elementos de gran interés (González Martínez, 2012). En el caso de la censura de El negro del Serafín, Navarro autorizó su representación (Madrid, 1643), si bien «reparando en ella lo que tengo apuntado en el margen desta tercera jornada en la hoja quince» así como «guardando las demás advertencias que tengo dichas y apuntadas en

\footnotetext{
${ }^{7}$ Volvemos a traer a colación la citada comedia calderoniana El José de las mujeres, de la que nos ocupamos por extenso más adelante, donde el copista Sebastián de Alarcón anotó al respecto de su traslado: «Se sacó del original de don Pedro Calderón para Manuel Vallejo, y va cierto y verdadero este traslado» (BNE, Ms. 16.548, f. 51r). Sin embargo, la censura de esta comedia es diez años posterior.
} 
ella». Pese a la meticulosidad del censor, «desgraciadamente no podemos saber a qué parte de la vida del santo puso el maestro Navarro reparos ya que la hoja quince del manuscrito ha sido arrancada» (Ruano, 1989: 225). En efecto, Navarro de Espinosa exige que se atienda su dictamen («También a las comedias hagiográficas lograba poner reparos nuestro concienzudo censor», dice Ruano), adelantándose a posibles justificaciones amparadas en las fuentes: «No siendo inconveniente el ser toda episodio de la vida deste santo, si bien en lo principal, que es lo importante, conviene con su historia, como consta de la corónica del seráfico San Francisco en la Cuarta Parte». La parte correspondiente a ese pasaje fue arrancada del manuscrito, y tan sólo ha quedado el pequeño resto de unas barbas en cuyo vuelto todavía se lee el final de algunas líneas; en el lugar donde se ubicaba el pasaje prohibido por el censor se insertaron otras páginas que parecen de diferente mano (ff. 15-17).

Pero el resto de intervenciones de Navarro de Espinosa en esta comedia son más interesantes si cabe. Ya en el f. 1v tacha el juramento «vive Dios»; en el f. 7v escribe «Alá» sobre otra tachadura; y un poco más adelante hace una curiosa anotación marginal que anticipa la advertencia posterior: al tachar parte de un juramento pronunciado por el negro protagonista («que vive Đios [Alá] que me corro»), y dado que tenía cierta obsesión por prohibir este tipo de juramentos (caso de El águila del agua, estudiado también por Ruano), se preocupa de aclarar que no lo hace como censor, y que se trata de la observación de un simple lector que advierte una incoherencia (que será subsanada, por cierto, en el «Vive Dios» tachado del f. 11r): «Mirad que decís unas veces Dios y otras Alá (no es como censor esta advertencia)» (f. 8r).

Es muy curioso también cómo tercia Navarro de Espinosa en su calidad de mero lector para sugerir (por medio de una llamada en forma de + ) una mejora en la resolución del final de la $1^{\mathrm{a}}$ jornada a propósito de la siguiente frase del Negro:

\footnotetext{
y finalmente que puede formar [?] de un impío. ${ }^{+}$

+ Mirad esta última vuesarced, que no es para acabar.
}

En cambio, sí interviene Navarro de nuevo como censor cuando tacha unos versos del gracioso Mortero sobre la señal de la santa cruz (ff. 8r-8v), o cuando señala en una nota marginal que «el santo no murió de herida», tachando los versos correspondientes (f. 18r), o cuando reconviene al autor de la comedia por otro pasaje relativo a la vida del santo en la escena de la estatua de Benedicto Esforcia que habla con el negro: «Este prodigio no está en su vida, pero hay otros mayores» (f. 19v).

La licencia extendida por Navarro de Espinosa para representar en Madrid El príncipe perseguido (comedia escrita en colaboración entre Belmonte Bermúdez, Moreto, Alarcón y Martínez de Meneses) muestra también los dife- 
rentes rostros y preocupaciones de este censor, quien hubo de examinarla dos veces en el plazo de cinco años: «He visto esta comedia y puede representarse», dijo en abril de 1645; «Se podrá repetir segunda vez en los teatros desta corte», decretó en octubre de 1650, convencido de la ejemplaridad de la obra: «Si bien es su historia humana, es tan piadosa y el caso tan decoroso y ejemplar, que puede pasar por divina» (BNE, Res. 81, f. 31v). Pero hizo además esta pequeña sinopsis y valoración: «El príncipe perseguido en ella es niño, y en sus adversidades se vale del asilo de San Francisco tomando su hábito, con que se libra del tirano que le persigue, siendo éste el mejor paso de la comedia». Hasta un nuevo título propuso este hacendoso censor: «Puede llamarse La inocencia perseguida y sagrado de Francisco, con que el nombre es más piadoso».

Algunas dudas acerca de si es o no de mano de Navarro de Espinosa una intervención textual nos plantea el caso de la comedia Vida y muerte de San Blas, escrita por un también desconocido Francisco de Soto y conservada en un manuscrito de 1658 (BNE, Ms. 17.117) que lleva unas notas de la censura algo desconcertantes. En primer lugar, entre la fecha de remisión a la censura y la de la licencia de representación pasaron nada menos que dos meses y medio (y más de un mes entre la nota del primer censor, Navarro, y la del segundo, fray Benito de Rivas). Tanto el severo Navarro como Rivas, calificador del Santo Oficio de la Inquisición, coincidieron en que esta comedia hagiográfica era muy fiel con las fuentes (historias eclesiásticas, martirologios) y tenía una gran potencialidad para mover a la devoción por San Blas, obispo de Sebaste (Armenia). Y ello a pesar de que, como ya hemos comentado, los censores normalmente eran reticentes en los casos de estas truculentas comedias de santos, muy dadas a los excesos. Ambos extendieron sus aprobaciones sin mayor problema, pero a última hora Navarro se dio cuenta de un olvido, y añadió al margen: «En la $3^{\mathrm{a}}$ jornada va una enmienda. Guárdese». Curiosamente, no podemos saber cuál es esa enmienda, pues no encontramos en esa tercera jornada nada que parezca haber sido prohibido por él. ¿Se equivocó el censor de jornada? Raro sería, pues era muy puntilloso con estas cuestiones (acabamos de leerle en su censura de El negro del Serafín avisar de una enmienda suya «en el margen de esta tercera jornada en la hoja quince»), pero ninguna de las palabras y versos tachados o modificados en esa $3^{\mathrm{a}}$ jornada parece que lo fueran sino por motivos literarios o teatrales.

En cambio, sí encontramos en la $1^{a}$ jornada una enmienda a una broma del gracioso Martín sobre la santidad del dormir, encabezada justamente por una acotación que ha sido tachada y reemplazada por esta otra (de letra no muy distinta a la de Navarro): «Sale Martín bajando por el monte al tablado»:

MARTín Saltando de rama en rama por estas breñas y riscos, con la mucha oscuridad, a Blas de vista he perdido. 


\author{
[...] \\ que solamente los lobos \\ saben dónde está el buen vino. \\ Hasta que vuelva a Sebaste \\ se malogró mi apetito. \\ Durmamos, pues no cenamos, $\S$ \\ que es también saneto ejereieio. \\ Mientras que el alba bosteza, \\ sobre estos verdes tomillos \\ tender pretendo la raspa, \\ que convida su olorcillo. \\ [...] (Duérmese y sale Blas con unos animales) (ff. 11r-11v).
}

La actividad censoria de Navarro de Espinosa deja otros numerosos ejemplos de este tipo. Uno de los más llamativos es el de La aurora del sol divino, de Francisco Jiménez Sedeño, de 1640 (BNE, Ms. 16.621). Pese a la aproximación inicial de Ruano a su censura (1989) y al estudio de González Román sobre su puesta en escena (1995), esta comedia ofrecía aún algunas incógnitas por despejar y numerosos elementos merecedores de un análisis detenido. Además de que hay dudas sobre la autoría, de que lleva una licencia de representación supuestamente extendida por Tirso de Molina (advirtiendo de rigurosos castigos para quien no se atuviera a las indicaciones de la censura), de que trata el espinoso asunto del dogma de la Inmaculada Concepción, y de que hay dudas en la interpretación de ciertas correcciones en una parte de la nota de la censura relativa a cómo debía hacer su papel la actriz que representaba a la Virgen, podemos encontrar en La aurora del sol divino intervenciones «poéticas» suyas, insertando algunos términos y versos de su propia cosecha para reemplazar lo que previamente había tachado a conciencia (incluso sobre el nuevo texto propuesto para sustituir lo censurado antes por él). Navarro de Espinosa dejó en su censura de La aurora del sol divino un curioso ramillete de protestas airadas contra determinados pasajes de la obra, con comentarios como los siguientes: «Estos son disparates», «No dice lo que quiere decir, ni lo que debe», «la Virgen no pudo decir esto», etc.; por falta de espacio, remitimos a un trabajo nuestro reciente para ampliar los detalles sobre este interesante caso (Urzáiz, 2012b), disponibles también en la base de datos del ClEMIT.

Otro caso muy interesante de obra hagiográfica donde aparece envuelto Navarro de Espinosa es el de Cegar para ver mejor, comedia sobre Santa Lucía escrita por Ambrosio Arce de los Reyes, que se conserva en un manuscrito de 1653 (BNE, Ms. 14.881) y que fue impresa en la Parte XIII de Escogidas (Madrid, 1660). Paz y Melia se limitaba a señalar sobre el manuscrito de Cegar para ver mejor que es autógrafo «en gran parte», que va firmado por el autor y que lleva «censuras de 1653»(1934: 88), pero el asunto es bastante más complejo y también le hemos dedicado algunos comentarios a su censura (Urzáiz, 2012b). En realidad, este códice es otra rica mina de in- 
formaciones de todo tipo: desde importantes cuestiones de tipo textual que no hacen ahora al caso (como las sustanciales diferencias entre la versión aquí recogida y la de la Parte, cuya $3^{\text {a }}$ jornada es radicalmente distinta), hasta pequeñas correcciones ortográficas, inusuales en una época anormativa: por ejemplo, ¿quién se preocupó de ir reemplazando las minúsculas iniciales del nombre de Marte, añadiendo al margen las emes mayúsculas correspondientes? ¿Sería tal vez el propio Navarro? A tenor de la caligrafía y la tinta es posible, aunque no podemos asegurarlo; algo parecido ocurre en el caso de los problemas textuales y de censura de la comedia de Rojas Zorrilla Abrir el ojo:

el corrector de este texto (quizá el dramaturgo Pedro Francisco Lanini Sagredo) detecta la falta del verso 47 [...] y completa por su cuenta la redondilla: «fui como alguna mujer». También sana el v. 91, deturpado [en otros testimonios] donde se atribuía a doña Hipólita un enunciado imposible en boca de una dama: «porque yo soy tan vieja» (heptasílabo); con buen conocimiento de la métrica y del corazón femenino, le bastó añadir un no para llegar a la frase que indudablemente había escrito Rojas: «porque yo no soy tan vieja» (Rodríguez Cáceres, 2011: 1280).

Podría decirse, parafraseando a Navarro de Espinosa, que no son como censor estas enmiendas... Y, por cierto, nos parece que va bien encaminada esa suposición de Milagros Rodríguez de que fuera el censor Lanini quien terció como poeta para subsanar las deficiencias del texto de Abrir el ojo, puesto que enseguida vamos a verle hacer algo parecido en la comedia Santa Catalina.

Probablemente también acierte Javier Rubiera al suponer que fue un censor quien llevó a cabo ciertos aportes de tipo poético sobre el texto de El José de las mujeres, Santa Eugenia, de Calderón, comedia a la que hemos aludido en un par de ocasiones. El firmante de la censura de El José de las mujeres es el también mencionado Juan de Rueda y Cuevas, quien provocó, con sus modificaciones textuales, desajustes en la atribución a los personajes de algunos parlamentos y en la escenificación de varios pasajes respecto a lo indicado en las acotaciones. Y es que este censor puso algunas objeciones a la posesión del cadáver de Aurelio por el Demonio:

[Que] se observe lo borrado y que el Demonio no entre en el cadáver, por ser herético y contra el Viejo y Nuevo Testamento, y contra la doctrina de los Santos Padres y Concilios, en especial contra cuatro Concilios Generales, como consta de la corrección hecha en la comedia que se trujo.

Madrid y noviembre 18 de 1679. El maestro don Juan de Rueda y Cuevas.

Pese a haber sido estudiadas con anterioridad por varios investigadores (Edward Wilson, Javier Aparicio, Agustín de la Granja), persistían también ciertos problemas con la transcripción de las notas de la censura y las modificaciones textuales de El José de las mujeres, parcialmente abordadas por 
Rubiera (pues aún quedan, dice, «algunas dudas en el aire»). Una de ellas tiene que ver con el hecho de que las intervenciones textuales del censor Rueda y Cuevas obligaron a que algunos versos fueran dichos por Aurelio, y no por el Demonio, variando así la puesta en escena original. Pero además hubo que insertar algunos otros de nuevo cuño para que actuaran como enlace y le dieran sentido a esa modificación operada sobre los parlamentarios:

\begin{tabular}{|c|c|}
\hline DEMONIO & $\begin{array}{l}\text { De aquestas perturbaciones } \\
\text { causa soy; y, pues que tengo } \\
\text { licencia de Dios, así } \\
\text { desde hoy perseguirte tengo. } \\
\text { [Por ordenación divina, } \\
\text { la forma tomo de Aurelio.] }\end{array}$ \\
\hline [AURELIO] & 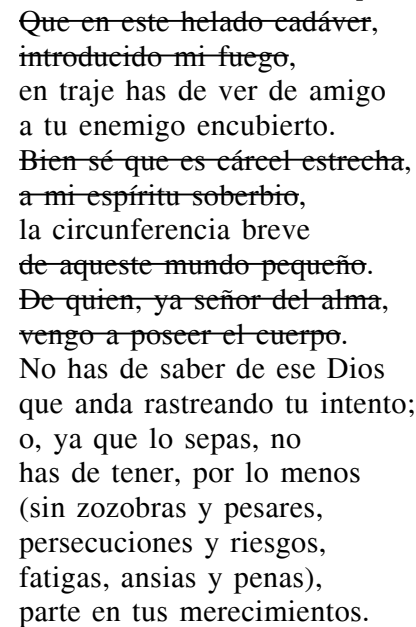 \\
\hline
\end{tabular}

Según Rubiera, estos nuevos versos son «de otra(s) mano(s)» distinta(s) de la del copista, pero no sabe si «pertenecen o no a la mano de Rueda y Cuevas, pues es posible que sobre la copia de Sebastián de Alarcón censurada por Rueda haya intervenido una tercera mano posteriormente». No podemos tampoco asegurarlo pero, atendiendo a su sugerencia «a futuros investigadores» de que se haga «un estudio riguroso del manuscrito completo [donde] se precise qué manos intervienen en él y se compare con otros textos de la mano de Rueda y Cuevas» (2011: 1319), hemos analizado esas intervenciones textuales y podemos aventurar las siguientes hipótesis. La primera intervención que menciona Rubiera (f. 17v) es una inserción marginal, escrita en vertical, de tres o cuatro versos; pero no parece la letra de Rueda ni es la tinta utilizada en su censura. La modificación que detecta poco después (f. 18r), correspondiente a la inserción de «Por ordenación divina, / la forma tomo de Aurelio», sí parece deberse a este censor, aunque la tinta es de un tono marrón diferente a la de su nota (más negra). La intervención del f. 43r, sobre 
la que Rubiera llama también la atención, parece un simple reemplazo del nombre de un parlamentario, que bien pudo deberse a Rueda.

Y, finalmente, la del f. 50v nos parece la más interesante y compleja, puesto que hay una intervención indudable de la censura: en determinado punto se aprecia (junto a la advertencia «ojo» y un verso tachado y reemplazado) una rúbrica característica de los censores cuando querían asegurarse de ser identificados y una serie de inserciones de palabras que, de nuevo, parecen de mano de Rueda (excepto la que dice «Yo difunto»):

\begin{tabular}{|c|c|c|}
\hline AURELIO & $\begin{array}{l}\text { Desamparando [la forma] } \\
\text { que }\end{array}$ & \\
\hline DEMONIO & $\begin{array}{l}\text { Que hasta este punto } \\
\text { pudo durar la licencia }\end{array}$ & \\
\hline & ojo de $x \times x$ [de fingir Aurelio & [rúbrica] \\
\hline CAPRICHO & Abernuncio. & \\
\hline CESARINO & ¡Ay de mí, infeliz, qué veo! & \\
\hline EAPRICHO & $\begin{array}{l}\text { Hacerse dos diablos de uno, } \\
\text { por apoearse. }\end{array}$ & no \\
\hline CESARINO & $\begin{array}{l}\text { Mortal } \\
\text { estoy. }\end{array}$ & \\
\hline CAPRICHO & ¿Qué dirá el difunto? [Yo difunto] & sí \\
\hline CESARINO & $\begin{array}{l}\text { ¿Quién eres, pálida sombra? } \\
\text { ¿Quién eres, horror caduco? }\end{array}$ & \\
\hline EAPRICHO & $\begin{array}{l}\text { Por no ver este espectáctlo, } \\
\text { volviera a ser eatecúmeno (f. } 50 \mathrm{v} \text { ). }\end{array}$ & no \\
\hline
\end{tabular}

Por otra parte, y a tenor de lo que reseñamos más abajo, no sería de extrañar que fuese Rueda y Cuevas el responsable de algunos de esos cambios, pues en más de una ocasión ejerció también este censor como arreglista-versificador: por ejemplo, y casualmente, en el manuscrito de Santa Catalina (como Pedro Lanini) o en el de Será lo que Dios quisiere, obra del propio Lanini, lo que da idea de la endogámica circularidad que llegaron a alcanzar a veces los circuitos de la censura teatral.

Hay incluso censores que lo eran de sí mismos en tanto que dramaturgos, y que se llegaban a desdoblar como juez o como padre de una misma obra. Estas últimas frases parecerían casi títulos de comedias (El censor de sí mismo, Como padre y como juez), pero remiten a un caso real, el del dramaturgo Andrés de Baeza, cuyas comedias El valor contra fortuna y No se pierden las finezas se publicaron en la Parte 11 de Comedias Escogidas (1658). Curiosamente, la aprobación de este volumen lleva también su firma, por lo que se vio obligado a dar la siguiente justificación:

En este libro he hallado, solicitada de ajena diligencia, una comedia mía, y por no faltar al precepto de obedecer a V.A., la he visto como juez, no como padre; y hallo que, si no en cuanto al acierto, en cuanto al decoro se puede imprimir como las otras. 
Volviendo al caso de Cegar para ver mejor, es muy interesante también la sucesión de dictámenes discrepantes a cargo de los varios censores que hubieron de examinar dicha comedia. En primera instancia recaería esta tarea sobre don Antonio de Nanclares, quien autorizó su representación pero bajo estas condiciones: «No diciendo lo que va borrado y rubricado, y la audiencia de Pascasio donde habla de los jueces y ministros» (f. 13r). Se envió luego la comedia a Navarro de Espinosa («como fiscal»), quien redactó un extenso e interesante texto, hoy casi ilegible, donde empieza señalando que «todos los que han escrito la vida desta santa no dicen que se sacase los ojos» y termina por dictaminar, casi resignado, que «se puede pasar [la escena de los ojos] en esta comedia» (a condición de que «se declare esto» en el texto) puesto que «en otra que hubo del mismo caso se puso el mismo inconveniente» y parece ser que fue poco atendido . $^{8}$.

Queremos llamar la atención sobre otra curiosa consideración del censor en la que habla de nuevo como experto degustador de teatro: tras explicar lo que dicen (y no dicen) las fuentes biográficas fidedignas y la contaminación con otros relatos («una monja, solicitándola un galán, viendo que su mayor incentivo nacía de sus ojos, se los envió con una criada; y el galán se convirtió y bautizó; y después, milagrosamente, los cobró, teniendo mejor vista»), y enredarse con asuntos iconográficos («[la sacan] pintándola con los ojos en el plato») y teológicos («[hubo] moción del Espíritu Santo, para que lo hiciese; que sin esta moción quien se cortase miembro [o] sacase los ojos pecaría mortalmente»), Navarro dice que «en lo demás no tiene reparo considerable» y reconoce que, al fin y al cabo, estas truculencias efectistas eran lo que la obra demandaba desde el punto de vista dramático: «En lo que se aparta de la historia de esta santa, es en lo forzoso que es necesario para hacer comedia, no apartándose ni contradiciendo en lo principal a la verdad de ella» (ff. 13r-13v).

El caso todavía habría de tener más recorrido, ya que la comedia fue remitida al Provisor ( $« \mathrm{El}$ reverendo padre maestro fray Miguel Guerrero vea este dicho paso»), quien dio el visto bueno final amparándose tanto en fuentes de autoridad como en la propia tradición iconográfica:

He visto con toda atención esta comedia, y en particular el reparo, y [...] basta la costumbre de la Iglesia, que pinta a $S^{\text {ta }}$ Lucía con los ojos en un plato. Y, fuera de esto, se comprueba esta costumbre antigua de nuestra madre Iglesia con la autoridad de San Gerónimo, que en la vida de esta santa, fol. 18, lo dice expresamente en un tomo pequeño que escribió de vidas de santos [...] (ff. 13v-14r).

\footnotetext{
${ }^{8}$ Navarro se quejó más de una vez de esto; por ejemplo, en la citada La aurora del sol divino, donde recuerda que sus advertencias anteriores sobre la inconveniencia de sacar a la Virgen a escena no se habían tenido en cuenta: «Y, supuesto que en otras no se ha hecho [el reparo de que la figura de Nuestra Señora no saliese al tablado], se podrá pasar en ésta, con prevención que...» (f. $48 \mathrm{v}$ ).
} 
Pero no fue éste el único pasaje problemático de Cegar para ver mejor, tal y como muestra la orden de volver a redactar la obra y enviarla de nuevo a la censura: «Esta comedia se traslade [...] quitando lo señalado y borrado, y tráigase» (f. $42 \mathrm{v}$ ). La mayor parte de los versos suprimidos por la censura son bromas del gracioso Chicharrón sobre vicarios, corregidores o doctores; alusiones teológicas («Đeseansó sin eansaneio, misterioso, / Đios al séptimo dł́a»); o chuscas propuestas para evitar los deslices de las mujeres casadas por medio de la clausura.

Señalemos, por último, que el autor de Cegar para ver mejor, Ambrosio Arce de los Reyes (?-1661), un presbítero madrileño que sólo ha dejado rastro en algunos festejos y certámenes poéticos, formó parte del nutrido grupo de dramaturgos que escribieron la comedia hagiográfica («de grandes tramoyas y aparatos») Vida y muerte de San Cayetano, prohibida en 1655 con gran escándalo público: «Estando para hacerse — cuenta el avisador Jerónimo de Barrionuevo-, la recogió la Inquisición». Pero «la reina se moría por verla, y las mujeres decían locuras», así que al final, tras haberla «escudriñado muy bien la Inquisición», se representó. Y «fue tanta la gente que acudió a verla al corral del Príncipe que al salir se ahogó un hombre entre los pies de los demás» (Díez Borque, 1996: 192). No se ahorró Barrionuevo el siguiente sarcasmo: «Buena ocasión tenía el santo, si quisiera, de hacer aquí un milagro. No debió de convenir».

Mucho le preocuparon también a Navarro de Espinosa ciertas escenas de la comedia Lo que toca al valor, de Mira de Amescua, sobre cuyo manuscrito (BNE, Ms. 18.071) actuó de forma llamativa. El códice es otra interesante copia de representación, con censuras de 1644 suyas y de otros; Navarro autoriza la representación, si bien «quitando de ella todo lo que va borrado»; y en ese todo se incluyen desde versos aislados (como éste del jactancioso príncipe de Orange: «a España eattso miedo») hasta escenas completas, como la del intento del propio Príncipe de violar a Isabel, que primero pide se haga decorosamente, sin recreaciones morbosas («Este paso se represente con las acciones muy honestas», dice -y subraya- en el f. $37 \mathrm{v}$ ), y finalmente prohíbe. La mayoría de los concienzudos tachones de Navarro recaen sobre intervenciones del gracioso Turín a propósito del honor, de las mujeres (doncellas, casadas y viudas), o de cómo debe zafarse un amante de aquellas a las que ya ha seducido; se suprimen también algunos cuentecillos, como uno que ocupa un extenso pasaje de un folio tachado casi en su totalidad, con las dos columnas enjauladas y el texto de reemplazo escrito verticalmente en el espacio entre ambas («Deja los cuentos agora» es la frase de nuevo cuño que sirve para zurcir el corte). Curiosamente, todas estas escenas censuradas por Navarro no aparecen tampoco en la versión impresa de Lo que toca al valor (Parte 34 de Comedias Nuevas, 1670), cuando lo habitual era que los versos prohibidos en la representación de las comedias sí aparecieran años después en sus respectivas ediciones, cuya censura era bastante más laxa. 
Es llamativo, en este sentido, el caso de Santa Catalina, mártir y doctora, la rosa de Alejandría, comedia de Pedro Rosete impresa en 1666 dentro de la Parte 24 de Escogidas y de la que se conserva un manuscrito casi veinte años posterior con gran parte de su texto expurgado por la censura. Aprovechando este caso, y para que no monopolice estas páginas Juan Navarro de Espinosa, veamos lo que dijeron otros colegas suyos que gustaban también de intervenir en cuestiones escénicas y literarias. El dramaturgo y censor Pedro Lanini fue uno de los tres examinadores de Santa Catalina (uno de ellos «de orden del señor Inquisidor General y demás señores de la Suprema Inquisición de España») que en 1684 dieron su aprobación para que se representara en Madrid, pero con algunas condiciones: «Observando que no se diga lo borrado, atajado y prevenido, no hallo cosa que se oponga...»; «arreglándose a lo que se previene en la censura»; «observando lo advertido...» (BNE, Ms. 14.986, ff. 57r-58v). Como advierte Valentín Azcune, «impreso y manuscrito ofrecen un amplio campo a los estudiosos de la censura teatral en el siglo XVII. En efecto, Lanini, censor del manuscrito, tachó numerosos versos, aunque casi todos pueden reconstruirse» (Azcune, 2000: 277). Y ello es posible gracias a la versión de las Escogidas, volumen de 1666 cuya aprobación había sido encomendada a Calderón de la Barca y donde se lee intacto casi todo lo censurado en el manuscrito de 1684: términos religiosos, matrimoniales, chistes del gracioso Trástulo sobre el pecado o los Mandamientos, etc.

Pero además de censurar muchos versos, Lanini también añadió algunos; por ejemplo, estos otros que no aparecen tampoco en la versión impresa y que completan los datos de la historia de Santa Catalina: el emperador Maximiano, desplazado a Alejandría, quiso poner a prueba la sabiduría de la joven filósofa (quien le había intentado convertir al cristianismo) enfrentándola en un debate a cincuenta filósofos. Al vencer Catalina, el emperador ordenó matar a todos los sabios excepto uno, que habría de casarse con ella; la negativa de ésta le costó el suplicio y la muerte. El texto del manuscrito lleva el siguiente añadido marginal, marcado con una + :

$$
\begin{array}{ll}
\text { LOS DOS } & \begin{array}{l}
\text { En esa fe moriremos, } \\
\text { [con otros cuarenta y ocho, }{ }^{9} \\
\text { vencidos con nuestro ejemplo]. }
\end{array} \\
\text { EMPERADOR } & \text { Llevaldos donde padezcan (f. 37r). }
\end{array}
$$

Veremos enseguida alguna otra puntualización suya de tipo histórico o geográfico en el texto de comedias de cuya censura tuvo que ocuparse. Pero no fue Lanini el único censor que intervino sobre el manuscrito de Santa Catalina. Es identificable también la letra de Rueda y Cuevas en un pasaje donde el Emperador hace sacar «el más sangriento y cruel instrumento» de tortura de Alejandría, «una rueda de navajas», para martirizar a Catalina,

\footnotetext{
${ }^{9} \mathrm{Al}$ lado rectificó la misma mano: «49».
} 
quien ha de tener «atadas las manos y vendados los ojos» mientras «baja el Ángel de rápido y pónese al lado» ${ }^{10}$. Ella parece mostrarse entonces entre desafiante y feliz por el inminente encuentro con Dios y se apresura, con voluntad suicida, a ser torturada, circunstancia que el censor matizó reemplazando un verso por otro que escribió tanto en el espacio interlineal como al margen derecho: «Contenta, al raro tormento / voy a arrojarme yo misma. [gran Jesús de mi vida]».

Otra obra hagiográfica revisada por Lanini fue $\mathrm{El}$ sol de Occidente, comedia sobre San Benito de Nursia escrita en 1697 por José de Cañizares, quien ejercería también durante mucho tiempo como censor (teniendo, por cierto, varios encontronazos con Lanini a causa de sus discrepancias). Ni Lanini como censor político, ni el doctor Agustín Gallo como censor eclesiástico, ni el fiscal Francisco Bueno encontraron nada sancionable en esta comedia, salvo algún error geográfico; así, junto a los versos que dicen «estos montes de Sublago, / cuarenta millas de Roma / (de la provincia de Lazio / desierto» anota Lanini: «Miente, que Sublago no está en el Lazio» (BNE, Res. 64, f. 7r).

Similares características tiene El bruto de Babilonia, de Matos Fragoso, Cáncer y Moreto, conservada en un manuscrito de 1669 (BNE, Ms. 15.041) e impresa en la Parte 30 de Escogidas (Madrid, 1668). Pieza de temática religiosa, en ella encontramos de nuevo una serie de curiosas puntualizaciones de los censores para corregir ciertos anacronismos. En el examen de esta comedia intervinieron el censor y dramaturgo Francisco de Avellaneda, el fiscal Fermín de Sarasa y el doctor Rueda y Cuevas, «de orden del Tribunal [de la] Suprema y General Inquisición» (entre la nota de remisión y la de este último también mediaron casi dos meses). Los censores prohibieron algunas bromas antisemitas que aludían de forma impropia al prendimiento de Jesús en el Huerto de los Olivos, o el papel de valido de Nabucodonosor que remedaba el gracioso Alcacer. Curiosamente, llegan a felicitarse entre sí por su perspicacia; así, si uno advierte que determinada frase va «Contra el cómputo de la Escriptura», otro ratifica el anacronismo: «Muy bien corregido».

Un caso poco frecuente, en la medida en que nos muestra el devenir de una comedia hagiográfica por las instancias de la censura a lo largo de casi setenta años (desde el pleno Barroco hasta el tardío), es el de Santa Táez. Escrita por el antes citado Enríquez Gómez (Zárate) y conservada en un manuscrito de representación de 1696 (BHM, Tea-1-61-9A), es una comedia de adúltera penitente sobre Santa Thais, rica cortesana de la Alejandría del siglo IV convertida al cristianismo tras ser instruida por el obispo egipcio San Paf-

\footnotetext{
${ }^{10}$ La historia de la santa cuenta, en efecto, que la máquina de ruedas con pinchos que el emperador Maximiano utilizó para torturarla se detuvo milagrosamente, rompiéndose al tocar su cuerpo. Catalina fue entonces decapitada y enterrada al pie del Monte Sinaí, donde se construyó un monasterio en torno al cual se producen peregrinaciones y leyendas sobre la aparición de su cuerpo intacto.
} 
nucio y recluirse durante largo tiempo en una celda conventual. Desde que en 1667 cayera en manos del también mencionado Avellaneda (que no era demasiado severo) hasta que tres censores autorizaran su representación en 1733 (uno de ellos precisamente Cañizares, ahora en el papel opuesto), y pasando por un total de once examinadores diferentes, el códice deja constancia de que Santa Táez se podía representar, pero siempre poniendo mucho énfasis en que fuera «observando lo que va atajado en la graciosidad por ser indecente», es decir, las bromas del ermitaño Balandrán, el gracioso de la comedia, chistes sobre la comida y el vino e irreverencias de contenido religioso (milagros, curaciones) como esta de tipo metateatral sobre los santos de tramoya:

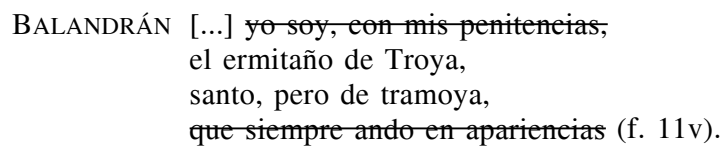

A propósito de las apariencias, en el manuscrito de una comedia sobre Santa Pelagia titulada La loca del cielo (BNE, Ms. 16.568), escrita por Diego Villegas en 1625, encontramos una curiosa preocupación de varios censores por que la práctica didascálica de esta pieza fuese decorosa: «Estas apariencias se hagan con decencia», pedía en Granada ${ }^{11}$ el doctor Martínez de Rueda; «Que las apariencias se hagan con la decencia que se requiere», insiste un par de meses después, en la provincia de Jaén, Antonio Blázquez del Castillo, quien se identifica como notario del Santo Oficio ${ }^{12}$ y dice haber «visitado esta comedia» por comisión particular de un miembro del Consejo Real; «Vista y [¿reconocida?] ${ }^{13}$, se da licencia se represente y las apariencias se hagan con decencia», reclamará en 1628, en Navarra ${ }^{14}$, el licenciado Pedro José de Urrutia. ¿Qué preocupaba tanto a los revisores de La loca del cielo, Santa Pelagia? Pues escenas como una en que la pecadora deja de ocultarse tras el disfraz de hombre y «Arroja los vestidos» al grito de «iAfuera lisonjas vanas, / prisiones de mis sentidos! / Con razón loca me llama / Antioquía»; o imágenes de esta otra adúltera penitente (antigua actriz por más señas), crucificada y colgada por los pelos:

Cáese la tapa de la cueva [...] y aparecerá la santa en una † colgada de los cabellos...

${ }^{11}$ En la descripción de este manuscrito en la Bibliografía de Rojas Zorrilla se transcribe sin identificar el lugar de la representación ni el día del mes: «en [...] Abril de / 1625»

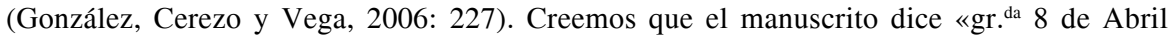
de / 1625».

${ }^{12}$ En la Bibliografía de Rojas se transcribe «sancto $\mathrm{Af}^{0} »$, pero creemos que dice claramente «sancto off ${ }^{\circ} »$.

${ }^{13}$ «Corregida», se transcribe en la Bibliografía de Rojas (González, Cerezo y Vega, 2006: 227).

${ }^{14}$ Aunque Paz ubica esta licencia «en Toledo, 29 de septiembre de 1628», creemos que dice «Tudela» y «diciembre»; en la Bibliografía de Rojas se corrige el error del mes, que no es septiembre («dez $\mathrm{z}^{\mathrm{e}}$, dice el manuscrito), pero se mantiene el de «Toledo» por «Tudela» (y hay otra licencia posterior para Pamplona). 
MúsICA Esta es Pelagia divina,

que hoy tan prudente camina

para ser loea del eielo (f. 48r).

Despues saldrá Pelagia enloquecida, «con sayo y sueltos los cabellos [...] mirando al cielo y corriendo por el tablado», mientras el Demonio combate con el Ángel por su alma: «Vuelve, señora, a mis brazos».

El Demonio es también protagonista en El más divino remedio, y aurora de San Ginés, de Alejandro Arboreda (BHM, Tea-1-49, f. 20v). Estrenada en 1684 por la compañía de Manuel de Mosquera, fue censurada por Rueda y Cuevas, quien, como es habitual, se identifica como comisionado inquisitorial para la censura previa: «De orden del señor Inquisidor General y demás señores de la Suprema Inquisición...». El doctor Rueda utilizó la misma fórmula de adscripción inquisitorial durante más de dos décadas (hemos visto, por ejemplo, sus censuras de El bruto de Babilonia en 1669 y de La hija del Serafín en 1678), lo que evidencia que no fue algo eventual, sino una costumbre que hay que contextualizar en las funciones de censura teatral preventiva que, al parecer (y en contra de la creencia generalizada de que sólo intervenía a veces con posterioridad al estreno ${ }^{15}$ ), desempeñó la Inquisición ya en el siglo XVII ${ }^{16}$. Sería el de Rueda un caso un poco distinto del de otro activo censor, fray Juan Bautista de Palacio, quien firmaba siempre sus licencias de representación identificándose como miembro de la Inquisición pero solía hacer constar que las extendía por encargo de vicario de su diócesis valenciana ${ }^{17}$; valga como ejemplo la de El purgatorio de San Patricio, de Calderón (1640): «Por orden de V.S., el señor Vicario General, he visto esta comedia [...] Fray Juan Bautista Palacio, cualificador del Santo Oficio». El propio Navarro de Espinosa, quien en 1652 hubo de volver a censurar esta comedia (que ya había visto en 1640), se refiere a Palacio en su aprobación como «calificador de la Suprema de Valencia» ${ }^{18}$.

Otros censores teatrales de la Valencia de aquella época se identifican

${ }^{15}$ La censura llamada «represiva», que llevaba a cabo la Inquisición tras producirse una denuncia; en estas páginas hay algunos ejemplos: El pleito del Demonio con la Virgen, Vida y muerte de San Cayetano o El negro del mejor amo, San Benito de Palermo.

${ }^{16}$ Recientemente hemos reseñado varios casos que así lo atestiguan, comentando por extenso alguno de ellos (Los tres portentos de Dios, de Vélez de Guevara; Lo que es ser predestinado, de Sandoval; La conversión de San Agustín, de Lope de Vega; Las órdenes militares, de Calderón, o La sombra y el sacristán) (Urzáiz, 2012a). Otros casos interesantes son los de La Gobernadora (1591), la Josephina de Carvajal (1599) o El lego del Carmen, San Franco de Sena, de Moreto (1657).

${ }^{17}$ A veces se fundían los ámbitos inquisitorial y diocesano en la misma persona; así, la licencia para Toledo, 1643, del auto Llamados y escogidos, de Calderón, se extendió en nombre de Andrés Fernández de Hipenza, «Inquisidor y Vicario General en la dicha ciudad y su arzobispado» (BNE, Res. 269).

${ }^{18}$ Precisamente en la labor como censor del trinitario Palacio hallaba Ruano de la Haza un elemento de contraste con la de Navarro: «Fray Juan Bautista Palacio y Juan Navarro de 
también como miembros de la Inquisición; así, el dominico fray Felipe de Salazar, teólogo de la Universidad de Valencia, aprobó en 1631 Cada loco con su tema, de Hurtado de Mendoza, como «calificador del Santo Oficio» (BNE, Res. 93). En este sentido, ya hemos señalado antes que uno de los censores que revisaron en 1625 La loca del cielo fue Antonio Blázquez del Castillo, notario de la Inquisición en Alcalá la Real; que fray Benito de Rivas, calificador del Santo Oficio, fue uno de los que censuraron, a mediados de siglo, la Vida y muerte de San Blas; que en 1664 fue la Inquisición de Toledo la que autorizó la representación de una comedia sobre la «Vida y muerte de Beatriz de Silva», La fundadora de la Santa Concepción; que en 1688 tenía «aprobada el Santo Tribunal de la Inquisición» la representación de Las misas de San Vicente Ferrer, de Enríquez Gómez, pese a lo cual el censor Lanini preguntó si era «necesario volverla a remitir al Santo Tribunal» (Domínguez de Paz, 2012); que Francisco Bueno pidió en 1699 que La conversión de la Magdalena, también de Enríquez Gómez, pasase «por el censor del Santo Tribunal» para que opinase sobre sus absurdos y herejías quien debía hacerlo. Al propio Bueno, fiscal de la Inquisición, le fue remitida en primera instancia, en 1694, El iris de las tormentas, caso que vamos a ver enseguida. Como vamos a ver también el de La gran Rosa de Viterbo, atentamente revisada por la Inquisición ya en el siglo XVIII (1702), época en la que esta práctica oficiosa de la censura inquisitorial previa se convertiría en oficial y sistemática ${ }^{19}$.

Volviendo a El más divino remedio, si Rueda no encontró motivo alguno de censura, en cambio al otro examinador (de nuevo Avellaneda, quien firmó su nota un mes después) le pareció también que podía representarse pero «observando lo que va atajado». El manuscrito presenta numerosas y diversas huellas de la intervención de la censura: rúbricas, «noes», «ojos» y asteriscos en los márgenes, advertencias teológicas y, sobre todo, tachones tan concienzudos que hacen a veces ilegibles los versos; es el caso del f. 22, donde Avellaneda rubrica hasta tres «noes», tachando siete versos sobre los que se han escrito sus co-

Espinosa representan polos opuestos dentro de la profesión de censor de comedias del Siglo de Oro. El primero podría servir de modelo para el tipo de censor que aprobaba comedias formulariamente y, probablemente, sin haberlas leído. El segundo, por el contrario, compendia al moralista severo y meticuloso que las examinaba circunstanciadamente» (Ruano, 1989: 228).

${ }^{19}$ Esto ocurrió a través de una cédula de 1725 , pero son abundantes los casos de comienzos de siglo en que aparece la Inquisición en la censura teatral previa: No muere quien vive en Dios (de Cañizares, 1700), El nacimiento del alba (de Lanini, 1701), El más dichoso en su patria (de Garcés, 1706), Peor es un tonto (de Morales, 1707), La organista del cielo (1713), El diablo mudo (de Calderón, 1713) o El prodigio de La Sagra (de Cañizares, 1723). Y hay también numerosos ejemplos de obras teatrales de comienzos del siglo anterior (1607, 1611) cuyas licencias de representación fueron extendidas «por mandado de los señores inquisidores» de Valladolid, Murcia y otros lugares (Urzáiz, 2012a: 292). 
rrespondientes alternativas textuales, dificultando la lectura y comprensión del pasaje. Los términos con connotaciones religiosas son los que parecen haber sido preferentemente censurados en esta comedia. En la $3^{\mathrm{a}}$ jornada hay otros versos de imposible lectura tachados a conciencia por el censor, quien deja en los márgenes sus advertencias teológicas. En el siguiente parlamento sólo censura una palabra, que no conseguimos leer (tal vez «divinidad») y para la que se propone otro término sustitutivo en el margen izquierdo:

$\begin{array}{ll}\text { MAICA } & \text { Que cuanto os dije, divina, } \\ & \text { fue inspiración de los cielos, } \\ & \text { que hay otro dios que domina, } \\ & \text { que aquella es su madre, y es } \\ & \\ & \text { la gracia que la previno... }\end{array}$

Un largo parlamento del viejo brujo Maica presenta catorce versos ilegibles, reemplazados por tan sólo cuatro escritos en el espacio interlineal: «tres personas padre, hijo / y espíritu, o no entendida / grandeza deste misterio / que incomprensible se admira»; al margen derecho, de letra más clara, se anota: «Tres personas / en una esencia divina, / padre, hijo y santo espíritu, / que altivo ser pues domina». Y después otras pequeñas correcciones a lo que Maica dice («Ved que ese bulto divino [sagrado]», «saero ministro» [«para instruirnos»], «el reino y la [adoración]»), subrayadas con estas advertencias: «*ojo», «Өjo corrxxxx ${ }^{\mathrm{d}} »$, «*sagrado ojo».

Otra comedia religiosa muy interesante es Será lo que Dios quisiere, de Pedro Lanini (quien hasta ahora ha concurrido en estas páginas en calidad de censor), conservada en un manuscrito con censuras de 1675. El primer examinador - Avellaneda, de nuevo - la aprobó sin problemas, incluso ensalzándola «por caso ejemplar». Pero dos días después la revisó Rueda y Cuevas, de nuevo por «orden de la Suprema y General Inquisición». El doctor Rueda (de mentalidad «algo más estrecha», Granja, 2006: 445) encontró que en la $1^{\mathrm{a}}$ jornada había algunas cosas que no se podían permitir:

Habiendo reconocido que, por ser el lugar las tablas, tiene inconveniente el hacer como que parezca sermón, no se haga; sino díganle las alabanzas a María Señora Nuestra en tal modo que antes muevan a devoción que causen escándalo por [¿parecer?] al pueblo que su acción grande[?] de elegir salvación se pasa a las tablas. Maestro don Juan de Rueda y Cuevas. [rúbrica] (ff. 34r-34v).

El pasaje que el censor inquisitorial temía que pudiera ser mal entendido por un auditorio poco formado (pues aludía al misterio de la Concepción de María, materia teológica de extrema sensibilidad) tenía repercusiones sobre otros momentos del desarrollo de la comedia, por lo que se tomó la molestia, por ejemplo, de tachar (muy concienzudamente) este otro para evitar incoherencias argumentales: 
Ojo: como no ha de haber sermón, se borra. [rúbrica del censor]

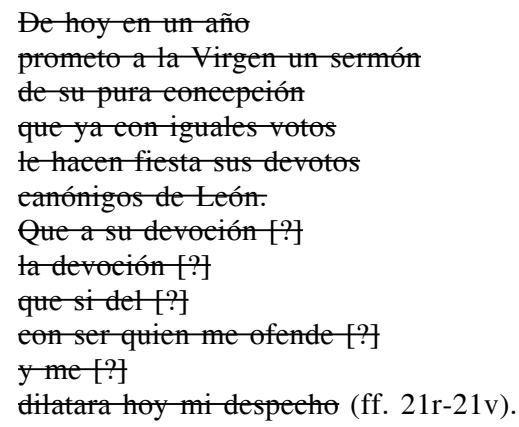

La frase de Rueda, más que una reprobación, es la advertencia de que el anuncio de Ludovico de hacerle un sermón a la Virgen no se diga. Y al final del códice vemos de nuevo la mano del censor anotando varias advertencias de «Ojo», junto a versos que aluden al episodio suprimido: «[...] haeerle venge a María / la fiesta que la ofreér»; «[...] yo ofreé́ a st eoneepeión / un sermón [...]» (ff. 46r-46v). Es decir, parafraseando de nuevo a Navarro de Espinosa, «no son como censor estas advertencias». Curiosamente, la versión impresa de Será lo que Dios quisiere presenta algunos cambios en lo referente a este pasaje: no aparece tampoco el polémico sermón, pero aquí sí que lo anuncia Ludovico, cometiéndose finalmente esa incoherencia que quiso evitar el puntilloso Rueda. Por cierto, que la versión impresa de esta comedia es la incluida en la Parte cuarenta y dos (1676), aprobada precisamente por... Avellaneda ${ }^{20}$.

El asunto de la Inmaculada Concepción es también el tema principal de otra comedia donde vuelve a aparecer el Demonio (esta vez en figura humana), cuyo manuscrito presenta huellas de la intervención de la censura (BNE, Ms. 17.022, con licencias de representación de 1663) y cuya versión impresa (Parte Sexta de Escogidas, 1654) parece que pudo ser prohibida por la Inquisición: El pleito del Demonio con la Virgen, una comedia anónima que Pedraza califica de «parahagiográfica» (2005: 969). En el manuscrito hay una anotación de la época que señala: «Ésta es muy buena comedia, pero está muy borrada» (f. 41v); y, en efecto, El pleito del Demonio con la Virgen presenta varios pasajes suprimidos por la censura, marcados con

${ }^{20}$ Cienfuegos apunta que la benévola censura de Avellaneda en el manuscrito puede deberse a que «pasara de puntillas sobre la intervención del inquisidor, al reconocerse de menor autoridad. Es posible, incluso, que ni leyera el manuscrito, al considerar a su autor garante de la pulcritud y corrección debidas» (Avellaneda, 2006: 37). Los datos que ahora añadimos sobre su intervención en la censura de la Parte, y algún otro que no hace ahora al caso pormenorizar (digamos simplemente que la letra de alguno de los textos de la censura no corresponde al nombre que lo firma) vienen a corroborar su sospecha. 
«noes» marginales acompañados de rúbricas. La mayoría de ellos corresponden a una serie de escenas cómicas de tipo entremesil, protagonizadas por los criados Inés, Lobaco y Alcaparrón, que contienen bromas de tipo sexual (con escenificaciones a veces muy osadas), chistes acerca de los Diez Mandamientos (sobre todo el Sexto, claro), sátiras de los cocheros, etc. Pero la censura más importante (estudiada recientemente por Cienfuegos, 2014) tiene que ver con un pasaje donde se polemiza, en un enconado debate entre los personajes de Carlos y Enrique (el Demonio con apariencia de hombre), sobre si «es María concebida / sin pecado original»o «como todos, pecó en Adán».

Otra comedia hagiográfica de interesante censura es la anónima El iris de las tormentas, conservada en un manuscrito de la BNE (Ms. 15.377) que contiene «aprobaciones del fiscal de la Inquisición y del censor Lanini Sagredo de mayo de 1694» (Paz y Melia, 1934: 26). El doctor Agustín Gallo Guerrero actuó, en efecto, como fiscal de la Inquisición (un nuevo ejemplo de su papel en la censura previa, éste de finales del siglo XVII), y no encontró reparo alguno en El iris de las tormentas; sí, en cambio, Pedro Lanini: «No se diga lo que va prevenido y atajado» (casi todo lo cual corresponde con parlamentos de los graciosos Mostachón y Celín, para cuya consulta detallada remitimos de nuevo a nuestros trabajos en papel (Urzáiz, 2012b) y, sobre todo, en la base de datos del CLEMIT).

Entrando ya en el siglo XVIII (como dijimos al principio, queremos cotejar, aunque sea someramente, la situación de la censura teatral en las primera décadas de la nueva centuria), La gran Rosa de Viterbo, de Francisco González de Bustos, dramatiza la vida de una iluminada niña predicadora, seguidora de San Francisco de Asís, a quien secundó en su renuncia a los bienes materiales. Con diez años, y tras unas visiones místicas, Santa Rosa de Viterbo (1234-1252) ingresó en la Tercera Orden de San Francisco, dedicándose a la caridad y la penitencia. Predicó por las calles de su ciudad con una cruz en la mano hasta conseguir que sus habitantes se alzaran contra el emperador Federico II de Alemania en defensa de la fe católica; pero el fervor de sus prédicas resultaba peligroso para el orden público y fue expulsada de Viterbo, incluso se le negó el ingreso en un monasterio por sus excesos en las penitencias y castigos corporales (cilicios, disciplinas, ayunos). La gran Rosa de Viterbo se conserva en un manuscrito de 1702 (BNE, Ms. 16.272-2) cuyas notas de censura, repartidas antes y después del texto (transcribimos sólo partes de algunas de ellas), revelan que fue atentamente revisada por la Inquisición:

Madrid y diciembre 10 de 1702 .

El autor lleve esta comedia al Santo Tribunal de la Inquisición para que mande se vea si tiene algo contra la santa fe [...].

De orden del Santo Tribunal de la Inquisición, he leído esta comedia intitulada Santa Rosa de Viterbo [...] Fray Matías de Burgos, calificador del Consejo. 
Señor Inquisidor don Gregorio Ramos. Represéntese esta comedia respecto de que, por la expurgación, no resulta cosa alguna.

Teniendo esta comedia de Santa Rosa de Viterbo un decreto para la Inquisición de 19 de diciembre y otro de 10 [¿16?] de este año, se saca por consecuencia que uno de ellos será para la censura política [...] Don José de Cañizares.

La leyenda de Rosa de Viterbo le atribuye predicciones proféticas y milagros; murió con unos dieciocho años, fue canonizada en 1457 por el papa Calixto III y su cuerpo incorrupto se conserva en una urna de oro y plata; según parece, los estudios forenses han descubierto que carece de esternón (fallo congénito provocado por un mal desarrollo cerebral). A la luz de estos datos, resulta curiosa la siguiente acotación, que lleva aparejada una intervención de la censura: «Desaparece Cristo en un rápido vuelo si se pudiere, y se pone Rosa de rodillas, y tomará una piedra para darse en los pechos» (f. $72 \mathrm{v}$ ). Un poco más adelante hay unos versos alusivos a estos golpes de pecho, pronunciados por el gracioso, que fueron recuadrados y tachados con grueso trazo (hasta hacer ilegible alguna palabra), probablemente por el censor:

TORONJIL Siguiendo a Rosa todo el pueblo hasta esta parte, llenando el campo de gritos, a bofetadas se abre, [el nácar de sus mejillas] $y$ el porrazo de los pechos strena a aldabazo de fuente etrando $x+x x x$ eonvidado (f. $75 \mathrm{v}$ ).

Justo a continuación, la misma pluma tachó llamativamente varias intervenciones del gracioso Toronjil (juramentos, chistes sobre alcahuetes y hermafroditas, herejes, frailes, conventos, etc.) que los demás personajes tildan de «desvergüenzas» y que se acompañan de indicaciones del tipo «No se diga», a veces incluso con el texto sustitutivo de mano del censor. Pero es llamativa, por contraste, esta otra pequeña censura que guarda relación más directa con la puesta en escena de La gran Rosa de Viterbo; se trata de un parlamento de Rosa al comienzo de la comedia (recuadrado, marcado con cinco noes, cruces potenzadas y ojos) tras el que cambia la letra, se anota « $1^{\text {a }}$ jornada de Santa Rosa de Viterbo» y se plantea un inicio distinto:

Bajará en una azucena la Virgen coronada de iris de luz, y a los lados dos ángeles que formarán trono hasta la mediación.

En empezando los versos de la Virgen se desprenderá el vástago de la azucena, a cuyo pie será la maceta en que Santa Rosa llegará a los pies de la Virgen... (ff. $6 \mathrm{r}-6 \mathrm{v}$ ).

Lo que cantan los ángeles es lo siguiente, donde se ha tachado una palabra junto a la cual se ha escrito una orden que parece de mano del censor Cañizares: 
ÁNGELES La azucena del cielo
gloriosa viene,
a ver, en una rosa,
más [las] candideces. [En lugar del más póngase otra cosa.] (f. 7v).

En efecto, en el espacio interlineal se ha añadido la palabra que sustituye a «más», como vuelve a ocurrir una página después, al repetirse los mismos versos. Obsérvese la fineza que había que tener para no incurrir en incorrecciones cuando la materia era religiosa: hasta una comparación tan ingenua podía juzgarse inapropiada.

El bello iris setabitano, de Gabriel Gámez, exalta la gracia que la Virgen de la Seo derrama sobre la ciudad de San Felipe-Játiva y los milagros obrados sobre sus devotos, a quienes libra continuamente de las tentaciones del Demonio. Se conserva en dos manuscritos de la BNE, uno de 1653 y otro con «dos censuras fechadas en Játiva en 1744, donde el autor se hallaba en octubre de ese año, según consta de la primera, ejerciendo la profesión de cómico» (Paz y Melia, 1934: 59). Este último contiene una licencia de representación firmada, «de orden del comisario del Santo Oficio», por fray José Gascón (prior y calificador también de la Inquisición), así como un largo e interesante dictamen apologético, firmado por el teólogo dominico fray Tomás Tarifa, donde se evidencia el cuidado con que se revisaba el teatro religioso. Pero en este caso, curiosamente, se prescinde de los argumentos de autoridad y ortodoxia dogmática, habituales en los censores para aprobar o no una obra («No ha tenido el autor para asunto de su idea noticia alguna histórica, o verdad autenticada en orden a esta imagen prodigiosa», sólo «su bien fundada fantasía» y los milagros que cuenta la vox populi), y el inquisidor encuentra el acierto de El bello iris Setabitano nada menos que en haber sido escrita directamente por «la mano del Altísimo».

Una comedia se convierte, pues, en una verdad revelada que andaba antes oculta y que se ha transmitido («empeñado en componer esta comedia el autor») al dictado de la Divina Providencia: «Para que tenga más visos de divina, ha querido Dios que no se le sepa su origen o descendencia, dejando su principio oculto entre las sombras de la antigüedad más respetuosa». Forma muy adecuada, entiende el teólogo, de que «el más incauto y disoluto conciba temor a enemigo tan furioso [como el Demonio], león rabioso que busca siempre al hombre su mayor extra[vío]» y de que hasta «el más inadvertido ánimo devotamente se aficione a esta sagrada imagen de María», gracias a «la eficacia de las voces, lo expresivo de los versos [...] el ornato cómico y el artificio métrico». Y, sobre todo, a «lo propio de las visiones», que «salen tan al vivo como si en su propia realidad se estuvieran mirando».

Se trata, pues, de un punto de vista sobre la justificación doctrinal y devocional del teatro religioso popular justamente antitético del que comentábamos al comienzo como característico de la censura teatral en la España de estos siglos. 
$\mathrm{Y}$, lejos de poder ser considerado como un indicio representativo de un supuesto cambio de mentalidad, nos parece que su principal interés reside precisamente en su pintoresca excepcionalidad: todavía no era éste el discurso oficial.

Aunque este repaso nos haya traído desde el establecimiento del modelo de la Comedia Nueva a comienzos del siglo XVII hasta casi la mitad del XVIII, no cabe entender este último testimonio de la censura teatral, tan entusiasta, como el reflejo de un cambio evolutivo del punto de vista oficial de la Iglesia española: en el ecuador del Siglo de las Luces, la jerarquía eclesiástica actuaba en sus distintos niveles con la misma animadversión contra el teatro, incluso contra aquel que servía como propaganda de su doctrina. Para comprobarlo, basta con dejar hablar a los textos, particularmente en esta modalidad de la que aquí nos hemos ocupado, los manuscritos de representación, donde han quedado infinidad de jalones de la intrahistoria teatral de aquellas épocas. Concluyamos, porque abrocha muy llamativamente con otros ejemplos citados antes, con uno de parecido tenor, el de La adúltera penitente (de Cáncer, Moreto y Matos Fragoso, los mismos autores que El bruto de Babilonia), en cuya nota de remisión a la censura el propio Protector de las Comedias resume con gran claridad el problema que venimos tratando:

Vean esta comedia de La adúltera penitente el censor, y después el fiscal, con el cuidado y atención que merecen estas materias de santas y de las graciosidades que suelen introducir, y tráigase con su censura.

Madrid a 12 de diciembre de 1669 (BNE, Ms. 14.915, ff. 15v-16r).

Obedientes, los examinadores (Avellaneda y Sarasa) vieron la comedia «con todo el cuidado que es de [su] obligación» y encontraron varias de esas reprobables graciosidades que solían introducir las comedias de santas. El Protector autorizó la representación de ésta, pero «observando lo atajado, y no de otra manera». La adúltera penitente es una comedia sobre Santa Teodora con varias intervenciones llamativas de la censura y presenta asimismo importantes diferencias textuales con sus versiones impresas, que sin duda se vinculan parcialmente con la propia acción censoria. Entre sus pasajes censurados rescatamos tan sólo un par de modificaciones que llevan aparejadas también pequeñas aportaciones textuales del propio censor Avellaneda (dramaturgo, al fin). Al lector que haya tenido la paciencia de seguir con atención los casos desgranados hasta aquí, le resultará curiosamente familiar esta pequeña admonición censoria:

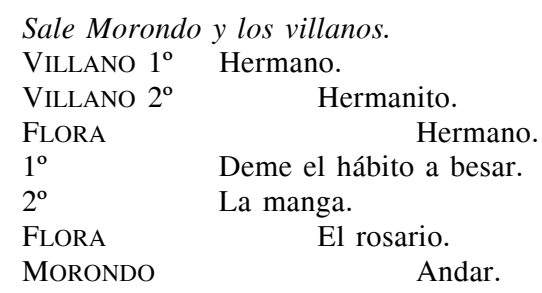




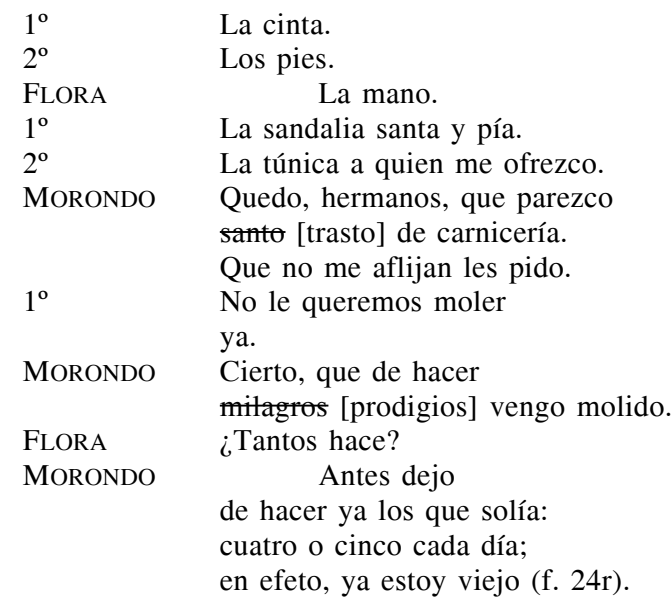

«No se diga santo», anotó y rubricó - al lado de este chiste sobre los santos de carnicería - Francisco de Avellaneda, quien dos años antes ya había salido también al paso de los antes comentados santos de tramoya. La truculencia y la rechifla sobre las tablas, habiendo por medio las cuestiones sagradas sobre las que giraban las comedias religiosas y hagiográficas, podían convertir el patio de comedias en una fiesta demasiado irreverente para lo tolerado en aquella época.

\section{BIBLIOGRAFÍA CITADA}

Avellaneda, Francisco de (2006). Teatro breve. Gema Cienfuegos Antelo (ed.) Madrid, Fundación Universitaria Española.

Azcune, Valentín (2000). «Miscelánea erudita», Cuadernos para Investigación de la Literatura Hispánica. 25, pp. 267-280.

Calderón de la Barca, Pedro (1988). El purgatorio de San Patricio. José María Ruano de la Haza (ed.). Liverpool: Liverpool University Press.

Cienfuegos Antelo, Gema (2014). «La polémica sobre el dogma de la Inmaculada Concepción y la censura teatral», Cincinnati Romance Review (Número monográfico: Javier Blasco y Héctor Urzáiz (ed.), Polémicas y controversias áureas). 37, pp. 24-44.

Díez Borque, José María (1996). Avisos del Madrid de los Austrias. Jerónimo de Barrionuevo (ed.). Madrid: Castalia.

Domínguez de Paz, Elisa (2012). «Las misas de San Vicente Ferrer, una controvertida comedia de Zárate censurada por la Inquisición (siglos XVII y XVIII)», Anagnórisis. 6, pp. 6-39.

Florit Durán, Francisco (2005). «Comedia hagiográfica y censura: el caso de La Santa Juana I de Tirso de Molina», en Marc Vitse (ed.), Homenaje a Henri Guerreiro. La hagiografía entre historia y literatura en la España de la Edad Media y del Siglo de Oro. Madrid: Iberoamericana-Vervuert, pp. 617-636.

González Cañal, Rafael, Ubaldo Cerezo Rubio y Germán Vega García-Luengos (2006). Bibliografía de Francisco de Rojas Zorrilla. Kassel: Reichenberger. 
González Martínez, Javier Jacobo (2012). «La transmisión impresa de un manuscrito dramático censurado: el caso de El santo negro, El negro del Serafín o El negro de mejor amor», Castilla. Estudios de Literatura. 3, pp. 403-417.

González Román, Carmen (1995). «La aurora del sol divino: una comedia representada en la Casa de Comedias Vieja de Málaga», En torno al teatro del Siglo de Oro. Actas Jornadas IX-X. Almería: Instituto de Estudios Almerienses, pp. 73-85.

Menéndez Peláez, Jesús (2005). «Teatro e Iglesia en el siglo XVI: de la reforma católica a la contrarreforma del Concilio de Trento», Criticón. 94-95, pp. 49-67.

Paz y Melia, Antonio (1934). Catálogo de las piezas de teatro que se conservan en el Departamento de Manuscritos de la Biblioteca Nacional. Madrid: Patronato de la Biblioteca Nacional, 2 vols.

Pedraza, Felipe (2005). «Rojas Zorrilla ante la comedia de santos: Santa Isabel, reina de Portugal», en Marc Vitse (ed.), Homenaje a Henri Guerreiro. La hagiografía entre historia y literatura en la España de la Edad Media y del Siglo de Oro. Madrid: Iberoamericana-Vervuert, pp. 967-983.

Ramos Smith, Maya (ed.) (1998). Censura y teatro novohispano (1539-1822). Ensayos y antología de documentos. México: Conaculta.

Río Barredo, María José del (1986). «Censura inquisitorial y teatro de 1707 a 1819», Hispania Sacra. 38-78, pp. 279-330.

Rodríguez Cáceres, Milagros (2011). «Los avatares textuales de Abrir el ojo de Rojas Zorrilla», en Antonio Azaustre Galiana y Santiago Fernández Mosquera (ed.), Compostella Aurea. Actas del VIII Congreso de la AISO. Santiago de Compostela: Universidad, pp. 1275-1285.

Roldán Pérez, Antonio (1998). "Censura civil y censura inquisitorial en el teatro del siglo XVIII», Revista de la Inquisición. 7, pp. 119-136.

Ruano de la Haza, José María (1989). «Dos censores de comedias de mediados del siglo XVII», en Francisco Mundi Pedret, Alberto Porqueras-Mayo y José-Carlos de Torres (ed.), Estudios sobre Calderón y el teatro de la Edad de Oro. Homenaje a Kurt y Roswitha Reichenberger. Barcelona: PPU, pp. 201-229.

Rubiera, Javier (2006). «Un demonio de ida y vuelta. Sobre la edición de las acotaciones en El José de las mujeres», en Anthony Close (ed.), Edad de Oro cantabrigense. Actas del VII Congreso de la Asociación Internacional del Siglo de Oro. Madrid: Iberoamericana-Vervuert, pp. 545-550.

Rubiera, Javier (2011). «Teología contra dramática: a vueltas con el demonio en El José de las mujeres calderoniano», en Antonio Azaustre Galiana y Santiago Fernández Mosquera (ed.), Compostella Aurea. Actas del VIII Congreso de la AISO. Santiago de Compostela: Universidad, pp. 1313-1320.

Urzáiz Tortajada, Héctor (2012a). «"Sacado de la profundidad de la Sagrada Escriptura”: la materia bíblica y la censura teatral áurea», en Francisco Domínguez Matito y Juan Antonio Martínez Berbel (ed.), La Biblia en el teatro español. Vigo: Academia del Hispanismo, pp. 283-304.

Urzáiz Tortajada, Héctor (2012b). «Tapándole las vergüenzas a la comedia: censura y teatro clásico», en Felipe Pedraza y Rafael González Cañal (ed.), La desvergüenza en la comedia española. Actas de las XXXIV Jornadas de Teatro Clásico de Almagro. Ciudad Real: Universidad de Castilla-La Mancha, pp. 179-215.

Urzáiz Tortajada, Héctor (2012c). «Expediente inquisitorial de Las misas de San Vicente Ferrer de Enríquez Gómez (1748)», Anagnórisis. Revista de investigación teatral. 6, pp. 40-63.

Fecha de recepción: 28 de enero de 2013.

Fecha de aceptación: 3 de julio de 2013.

Revista de Literatura, 2015, vol. LXXVII, n. ${ }^{\circ}$ 153, 47-73, ISSN: 0034-849X, doi: 10.3989/revliteratura.2015.01.002 